\title{
Mechanism of Endothelial Cell Shape Change in Oxidant Injury
}

\author{
Daniel B. Hinshaw, M.D., ${ }^{1}$ Jeanne M. Burger, B.S., Barbara C. ARMstrong, B.A., \\ AND PAUl A. Hyslop, PH.D. $\dagger$ \\ Departments of Surgery, University of Michigan and Ann Arbor VA Medical Center, Ann Arbor, Michigan 48105; ${ }^{*}$ McGuire VA Medical Center, \\ Richmond, Virginia; and + Lilly Research Laboratories, Indianapolis, Indiana
}

Presented at the Annual Meeting of the Association for Academic Surgery, Salt Lake City, Utah, November 16-19, 1988

Changes in endothelial cell morphology induced by neutrophil-generated hydrogen peroxide $\left(\mathrm{H}_{2} \mathrm{O}_{2}\right)$ may account for the capillary leak of the adult respiratory distress syndrome (ARDS). The relationship of $\mathrm{H}_{2} \mathrm{O}_{2}$ effects on the concentration of intracellular $\mathrm{Ca}^{2+}\left(\left[\mathrm{Ca}^{2+}\right]_{i}\right)$ and ATP to changes in microflaments and microtubules, important determinants of cell shape, was examined. Bovine pulmonary artery endothelial cells were injured over a 2-hr time course with a range of $\mathrm{H}_{2} \mathrm{O}_{2}$ doses $(0-20 \mathrm{mM})$. The higher concentrations of $\mathrm{H}_{2} \mathrm{O}_{2}$ consistently produced contraction and rounding of $>50-75 \%$ of cells by $1-2 \mathrm{hr}$. The range of 1-20 $\mathrm{mM} \mathrm{H} \mathrm{H}_{2} \mathrm{O}_{2}$ produced rapid, significant reductions in endothelial ATP levels over the time course of injury. Although there were significant increases in mean endothelial $\left[\mathrm{Ca}^{2+}\right]_{1}$ in response to 5,10 , and $20 \mathrm{mM}$ $\mathrm{H}_{2} \mathrm{O}_{2}, 1 \mathrm{mM} \mathrm{H}_{2} \mathrm{O}_{2}$ did not affect the $\left[\mathrm{Ca}^{2+}\right]_{1}$. Fluorescence microscopy revealed that microfilament disruption occurred as ATP levels fell and preceded depolymerization of microtubules which developed after $\left[\mathrm{Ca}^{2+}\right]_{1}$ approached $1 \times 10^{-6} M . \mathrm{H}_{2} \mathrm{O}_{2}$ at $1 \mathrm{mM}$ injury caused microfilament disruption but did not depolymerize microtubules. Microfilament disruption occurred without oxidant exposure, when ATP levels were reduced by glucose depletion and mitochondrial inhibition with oligomycin $(650 \mathrm{nM})$. If a $\mathrm{Ca}^{2+}$ ionophore, ionomycin $(5 \mu M)$, was then added, $\left[\mathrm{Ca}^{2+}\right]_{i}$ rose to $>1 \times 10^{-6} \mathrm{M}$, microtubules fragmented and depolymerized, and cell contraction and rounding very similar to that induced by $\mathrm{H}_{2} \mathrm{O}_{2}$ occurred. These results suggest that endothelial cell dysfunction and capillary leak in ARDS may be due to $\mathrm{H}_{2} \mathrm{O}_{2}$-mediated changes in cellular ATP and $\left[\mathrm{Ca}^{2+}\right]_{i}$. (c) 1989 Academic Press, Inc.

\section{INTRODUCTION}

Endothelial cells form a major part of the normal capillary permeability barrier. Changes in endothelial cell shape which occur during inflammation (e.g., ARDS) have been associated with increased capillary permeability [1-

\footnotetext{
${ }^{1}$ To whom reprint requests should be addressed at Surgical Service (112), VA Medical Center, 2215 Fuller Road, Ann Arbor, MI 48105.
}

3]. Work with a variety of cell types including endothelial cells has demonstrated their ability to form tight junctions and act as permeability barriers when grown as monolayers on micropore filters [4-9]. The model permeability barriers lost their functional integrity when exposed to agents causing cell injury. Activated polymorphonuclear leukocytes (PMN) [9], superoxide anion $\left(\mathrm{O}_{2}^{-}\right)$[7], $\mathrm{H}_{2} \mathrm{O}_{2}$ [8], the $\mathrm{Ca}^{2+}$ ionophore A23187 [7], and cytochalasins [5, 6] were capable of disrupting the in vitro permeability barriers. Cytochalasins and activated PMN, which produce a number of different oxidants including $\mathrm{O}_{2}^{-}$, hydroxyl radical $(\mathrm{OH} \cdot)$, hypohalous acids, and $\mathrm{H}_{2} \mathrm{O}_{2}[6,9]$ have also been shown to be capable of causing capillary leak in isolated perfused lungs. Constant infusion of micromolar quantities of $\mathrm{H}_{2} \mathrm{O}_{2}$ in an isolated-perfused lung model also produced significant capillary leak over a 90 min time course [10]. Injury in the model systems was associated with cytoskeletal changes and gap formation between cells which correlated with loss of transmembrane electrical resistance and increased permeability of the monolayers to albumin [4-7].

Two major cytoskeletal structures involved in maintaining cell shape are microfilaments and microtubules.

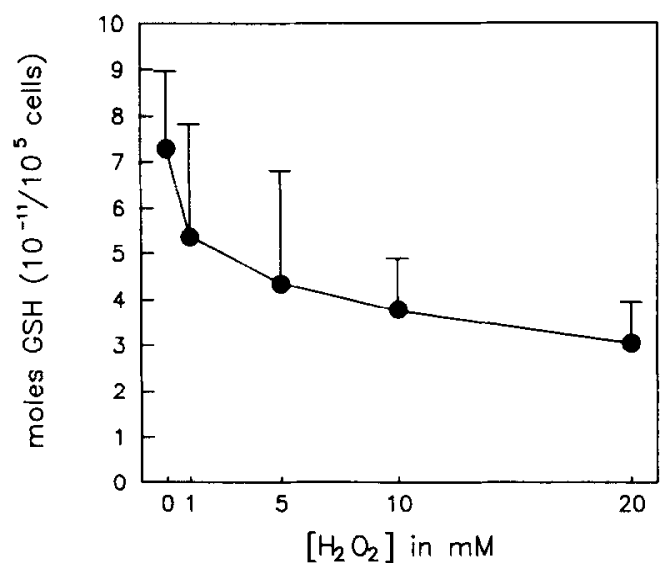

FIG. 1. Dose response of total glutathione levels in bovine pulmonary artery endothelial cells $60 \mathrm{~min}$ after exposure to $0-20 \mathrm{mM} \mathrm{H}_{2} \mathrm{O}_{2}$. Data points represent the means \pm standard deviations from at least six separate determinations. 


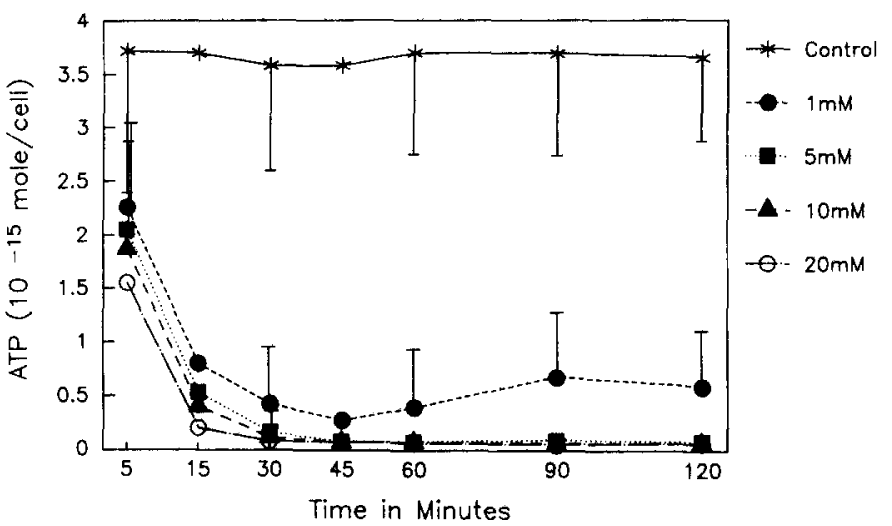

FIG. 2. Dose response and time course of mean endothelial cell ATP levels following exposure to $\mathrm{H}_{2} \mathrm{O}_{2}$. Data points represent the means of five to seven separate determinations. To avoid confusion from crowding of symbols, representative standard deviation bars have been depicted in the figure. Maximal declines in ATP levels seen at later time points with the higher doses of $\mathrm{H}_{2} \mathrm{O}_{2}$ were $<2 \%$ of control levels.

Microfilaments, primarily composed of the protein actin, play an important role in cellular adherence to other cells or to the extracellular matrix (basement membrane) [11, 12]. Microtubules made up of polymers of the protein tubulin also lend support to overall cell shape and are quite sensitive to elevation of intracellular $\mathrm{Ca}^{2+}$ to levels $\geqslant 1 \mu M$ which can cause depolymerization $[13,14]$.

Oxidant injury has been associated with a number of adverse biochemical events. $\mathrm{H}_{2} \mathrm{O}_{2}$ produced rapid reduction of ATP levels in target cells by inhibition of the glycolytic enzyme, glyceraldehyde-3-phosphate dehydrogenase, and inhibition of mitochondrial ADP phosphorylation $[15,16]$. Intracellular $\mathrm{Ca}^{2+}$ levels in the $\mathrm{P}^{2} 88 \mathrm{D}_{1}$ cell line also rose in response to $\mathrm{H}_{2} \mathrm{O}_{2}$ injury [17]. DNA damage with strand breakage and activation of the nuclear enzyme poly(ADP) ribose polymerase occurred rapidly following $\mathrm{H}_{2} \mathrm{O}_{2}$ exposure [18]. Gross changes in surface morphology (membrane blebbing) and disruption of the cytoskeleton with formation of microfilament bundles developed as the injury progressed [19]. The microfilament disruption into bundles was found to be an ATPdependent phenomenon which could be reproduced by metabolic inhibition without oxidant exposure [20,21].

The approximate threshold level of ATP in endothelial cells for microfilament disruption and bundle formation

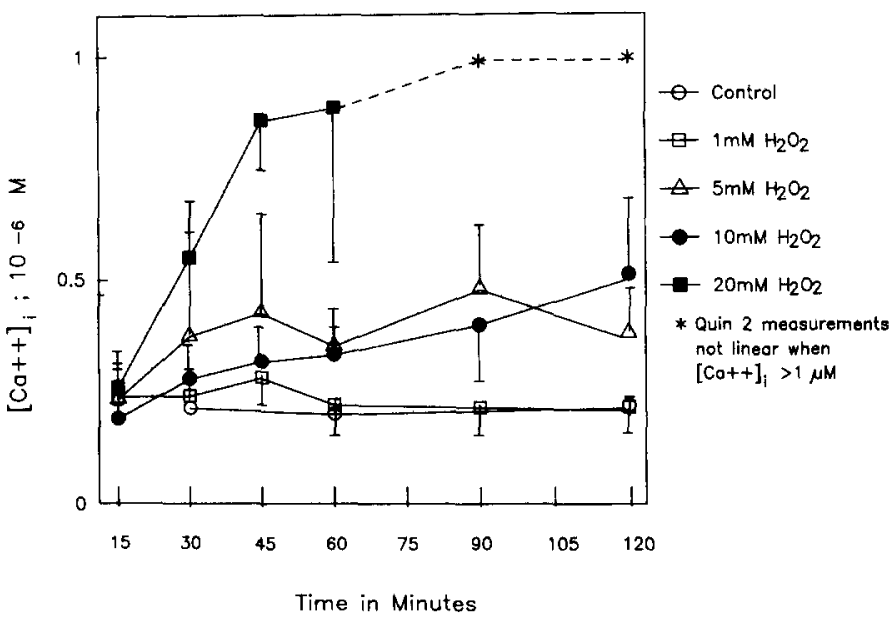

FIG. 3. Dose response and time course of mean endothelial $\left[\mathrm{Ca}^{2+}\right]_{\mathrm{i}}$ following exposure to $\mathrm{H}_{2} \mathrm{O}_{2}$. Data points represent the means \pm standard deviations of 4-14 separate determinations. Most experiments were repeated five or six times. Asterisks at 90 and $120 \mathrm{~min}$ on the $20 \mathrm{mM} \mathrm{H}_{2} \mathrm{O}_{2}$ curve represent $\left[\mathrm{Ca}^{2+}\right]_{i}>1 \mu M$. Since Quin 2 measurements above this level are nonlinear, the real $\left[\mathrm{Ca}^{2+}\right]_{i}$ may be as high as the millimolar range.

was $15-20 \%$ of normal levels [20]. The ATP-dependent changes in microfilament organization were independent of any net change in polymerized actin within the cell [21]. The microfilament bundle formation was reversible if ATP synthesis could be restored [20].

Holman et al. [22] recently demonstrated with an in vitro permeability model that oxidant-induced increases in permeability were associated with a fall in endothelial cell ATP levels.

The relationship between oxidant-mediated effects on ATP levels and intracellular $\mathrm{Ca}^{2+}$ regulation and the cytoskeleton in unclear. We examined the effect of a range of $\mathrm{H}_{2} \mathrm{O}_{2}$ doses given as a single bolus on ATP levels and the intracellular $\mathrm{Ca}^{2+}$ concentration $\left(\left[\mathrm{Ca}^{2+}\right]_{i}\right)$ in bovine pulmonary artery endothelial cells. These relationships were then correlated to concurrent changes in the organization of microfilaments and microtubules and associated morphology in injured cells. The effects of altering endothelial ATP and $\left[\mathrm{Ca}^{2+}\right]_{i}$ independent of oxidant injury on cytoskeletal organization and cellular morphology were also examined.

FIG. 4. Fluorescence micrographs of adherent bovine pulmonary artery endothelial cells 60 min after $\mathrm{H}_{2} \mathrm{O}_{2}$ exposure. (A) Control endothelial cells stained with rhodamine phalloidin for microfilaments (400X magnification). Note the normal distribution of microfilaments parallel to the cell membrane or long axis of the spreading cells. (B) Control endothelial cells stained with double antibody technique for microtubules (400X magnification). Note the radial distribution of normal microtubule architecture emanating from the nuclear region of the cells. (C) Adherent endathelial cells stained with NBD-phallacidin for microfilaments 60 min after addition of $5 \mathrm{mM} \mathrm{H}_{2} \mathrm{O}_{2}$ (400X magnification). Note the disruption of microfilaments into brightly staining shortened aggregates within the injured cells. (D) Adherent endothelial cells stained with double antibody

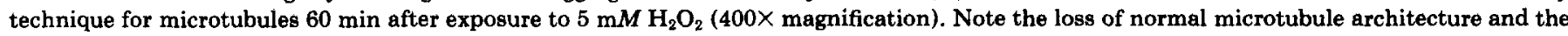
predominance of staining around the nucleus. (E) Adherent endothelial cells stained with NBD-phallacidin for microfilaments 60 min after exposure to $1 \mathrm{mM} \mathrm{H}_{2} \mathrm{O}_{2}$ (1000× magnification, same field as in $\mathrm{F}$ ). Note the loss of normal microfilament architecture similar to that seen in $\mathrm{C}$. (F) Adherent endothelial cells stained with double antibody technique for microtubules $60 \mathrm{~min}$ after exposure to $1 \mathrm{mM} \mathrm{H}_{2} \mathrm{O}_{2}(1000 \times$ magnification). Note the normal microtubule organization and the less pronounced changes in cell morphology in $\mathrm{E}$ and $\mathrm{F}$ as compared to $\mathrm{C}$ and $\mathrm{D}$. 

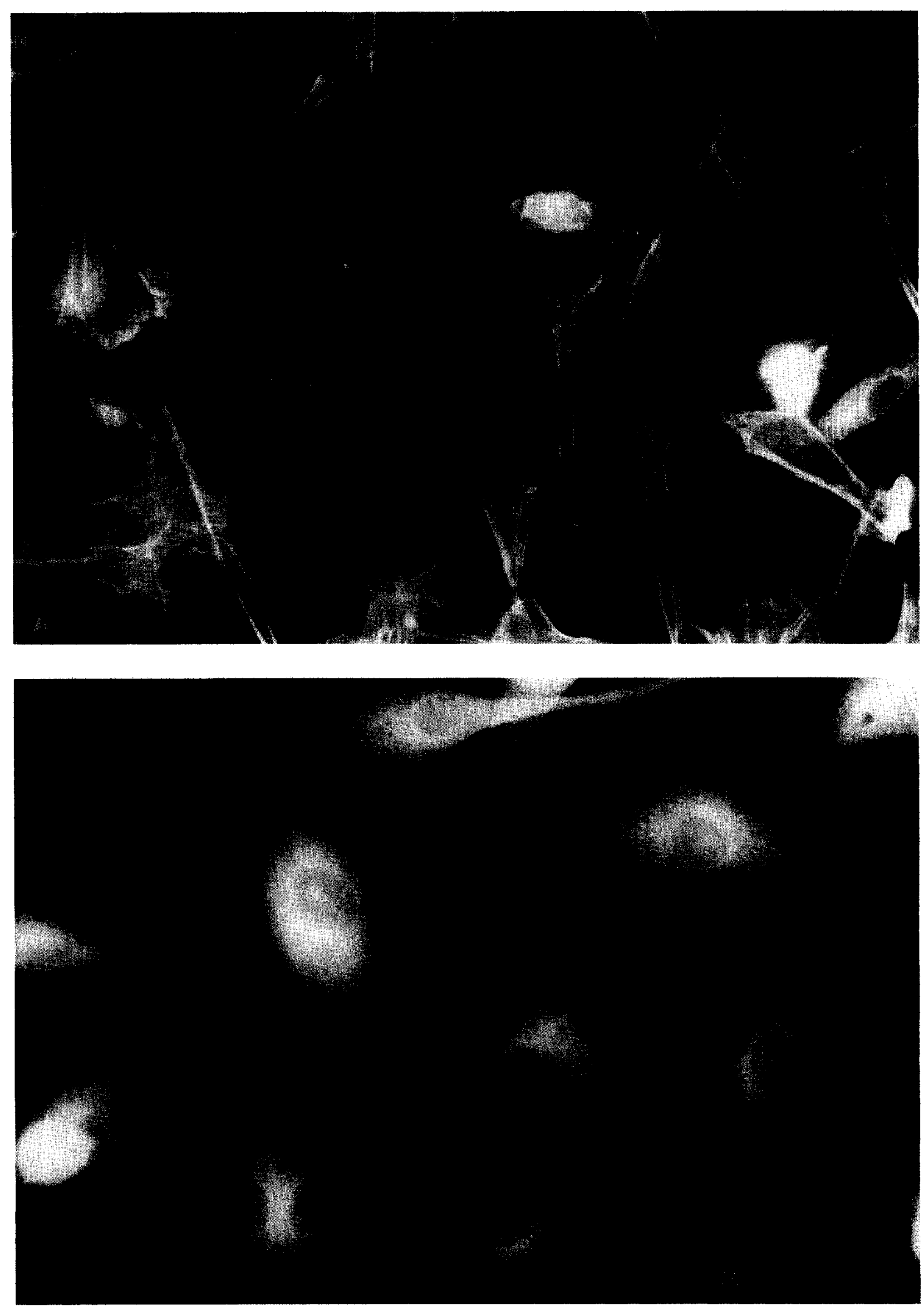

FIG. 4-Continued 

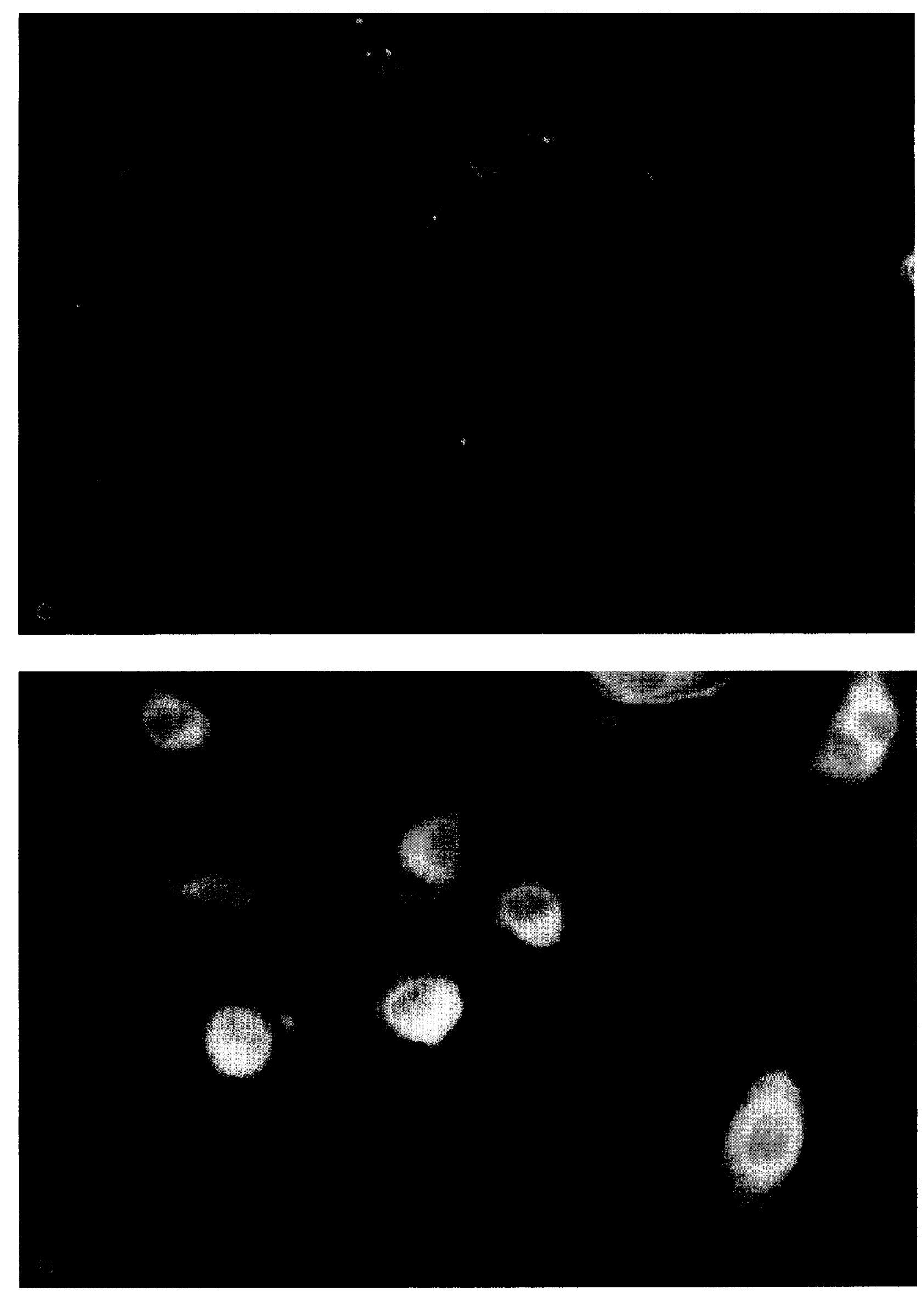

FIG. 4-Continued 

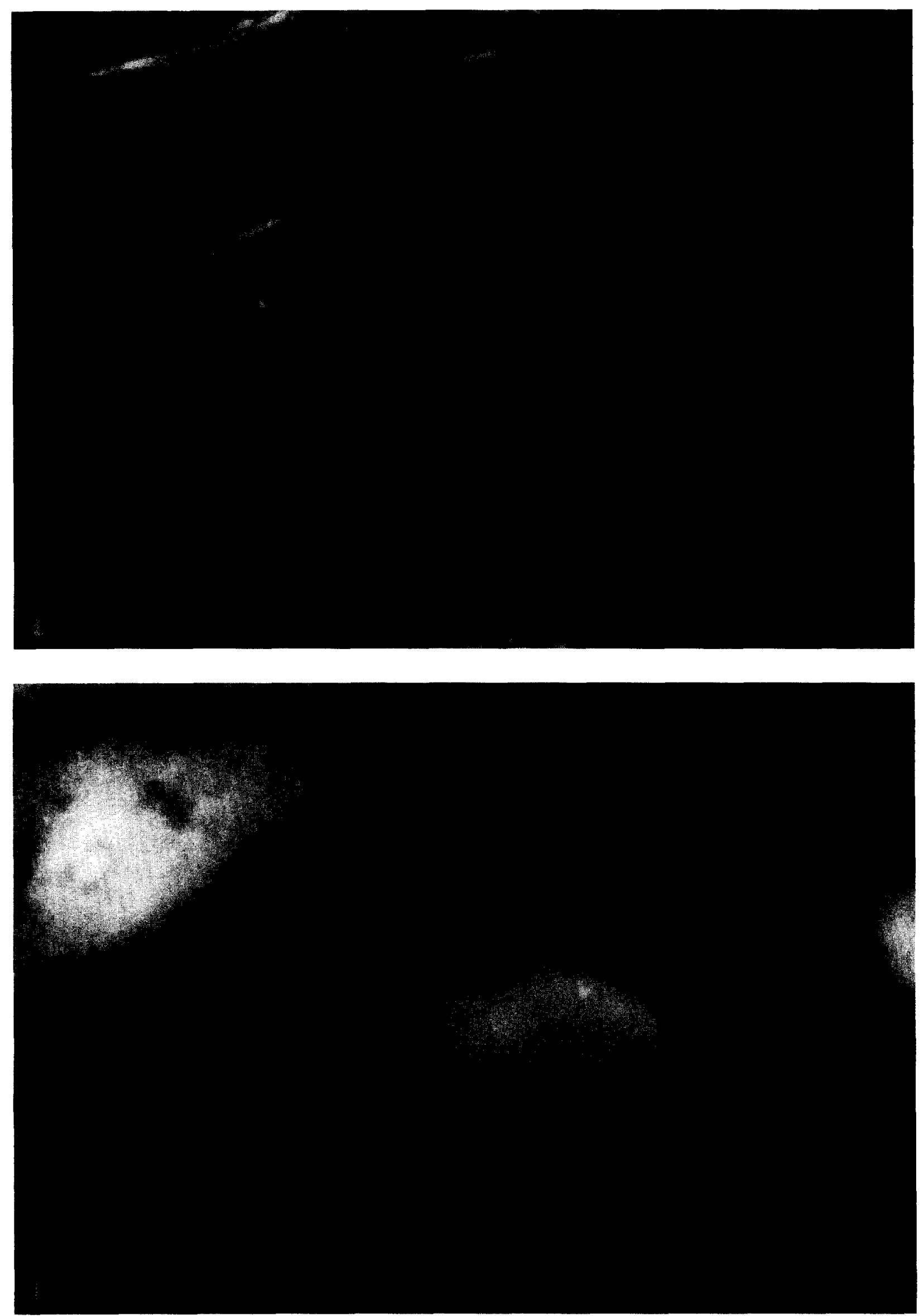

FIG. 4 Continued 


\section{METHODS}

\section{Cells and Culture}

Bovine pulmonary artery endothelial cells (No. AG 2791 A) from the National Institute of Aging, Aging Cell Culture Repository (Camden, N.J.) were grown to confluence in $150-\mathrm{cm}^{2}$ flasks (Corning). They were cultured in RPMI 1640 supplemented with $10 \%$ fetal bovine serum (Whittaker, M.A. Bioproducts), $2 \mathrm{mM}$ glutamine (GIBCO), 10 $\mathrm{m} M$ Hepes (Whittaker, M.A. Bioproducts), $100 \mathrm{u} / \mathrm{ml}$ penicillin, and $100 \mu \mathrm{g} / \mathrm{ml}$ streptomycin (GIBCO). Cells were passaged after a brief exposure (10-15 $\mathrm{min}$ ) to trypsin $(0.05 \%)$ and EDTA (0.02\%; Sigma). The cells were suspended at a concentration of $2 \times 10^{6} / \mathrm{ml}$ in modified Gey's buffer (MGB) containing $147 \mathrm{mM} \mathrm{NaCl}, 5 \mathrm{mM} \mathrm{KCl}$, $1.9 \mathrm{mM} \mathrm{KH}_{2} \mathrm{PO}_{4}, 1.1 \mathrm{mM} \mathrm{Na} \mathrm{HPO}_{4}, 0.3 \mathrm{mM} \mathrm{MgSO}_{4}, 1$ $\mathrm{m} M \mathrm{MgCl}_{2}$, $5.5 \mathrm{mM}$ glucose, $10 \mathrm{~m} M$ Hepes, and $1.5 \mathrm{mM}$ $\mathrm{CaCl}_{2}$. In some experiments, glucose was absent from the buffer.

Experiments with suspended cells were carried out at $37^{\circ} \mathrm{C}$ in a shaking water bath.

\section{Glutathione (GSH) Measurements}

Measurement of total GSH was performed using the method of Brehe and Burch [23]. Briefly, $5 \times 10^{6}$ cells were centrifuged for $30 \mathrm{sec}$ in a microcentrifuge, the supernatant was removed, and the pellet was deproteinized with $200 \mu \mathrm{l} 2.5 \%$ sulfosalicylic acid in $0.2 \%$ Triton $X-100$. Following another centrifugation, determinations of total acid soluble GSH were made in plastic cuvettes using 25$\mu \mathrm{l}$ samples after addition of $500 \mu \mathrm{l} 0.3 \mathrm{mM} 5,5^{\prime}$-dithiobis2-nitrobenzoic acid (DTNB), $500 \mu \mathrm{l} 0.4 \mathrm{mM}$ NADPH containing $0.12 \mathrm{u}$ glutathione reductase, and $500 \mu \mathrm{l}$ phosphate/imidazole buffer, $\mathrm{pH}$ 7.2. The difference in optical density at $412 \mathrm{~nm}$ was read on a Gilford Model 250 spectrophotometer.

\section{ATP Determinations}

Endothelial cell ATP levels were measured by the luciferase-luciferin method of Stanley and Williams [24] as previously adapted $[15,21]$. The luciferase-luciferin (Sigma No. LO633) was reconstituted at $40 \mathrm{mg} / \mathrm{ml}$ in sterile water and diluted 1:50 in a buffer containing $1 \%$ bovine serum albumin, $20 \mathrm{~m} M$ glycine, and $2 \mathrm{mM}$ EDTA, pH 8.0. Measurements were performed in a LKB model 1251 automated luminometer. ATP measurements were normalized so they could be expressed as the mean ATP level per cell.

\section{Measurement of $\left[\mathrm{Ca}^{2+}\right]_{i}$ with Quin 2}

Endothelial cells in suspension were loaded with the acetoxy-methyl ester of Quin 2 (Quin 2 AM; Amersham, Arlington Heights, IL) after the method of Tsien et al. [25] as previously modified [17]. Aliquots of $5 \mathrm{mM}$ Quin 2 AM (reconstituted in DMSO) were added to gently stirred cells $\left(10 \mu \mathrm{l} / 10^{7}\right.$ cells $\left./ \mathrm{ml}\right)$ at $1 \mu \mathrm{l} / \mathrm{sec}$ and then incubated on a rotational device at $37^{\circ} \mathrm{C}$ for $25-30$ min until maximal uptake was achieved. After a wash step using MGB and a brief ( $5 \mathrm{~min}$ ) centrifugation at $1500 \mathrm{rpm}$, the cells were resuspended in MGB at $2 \times 10^{6}$ cells $/ \mathrm{ml}$.

Quin 2 fluorescence was read on a spectrofluorometer (Perkin Elmer LS5; modified for work with thermostated, stirred cell suspensions) with an excitation wave length of $340 \mathrm{~nm}$ and an emission wave length of $520 \mathrm{~nm}$. Fluorescence intensity $(F)$ was measured directly on $1.5-\mathrm{ml}$ stirred samples at $37^{\circ} \mathrm{C}$. Maximum fluorescence $\left(F_{\max }\right)$ was determined after detergent lysis $(10 \mu \mathrm{l} / \mathrm{ml}, 1 \%$ Triton $\mathrm{X}-100)$. Minimal fluorescence $\left(F_{\min }\right)$ was measured after the addition of $50 \mu$ l of $0.7 M$ EGTA to chelate all $\mathrm{Ca}^{2+}$ present. $\left[\mathrm{Ca}^{2+}\right]_{i}$ was determined using the following equation: $\left[\mathrm{Ca}^{2+}\right]_{\mathrm{i}}=115 \times 10^{-9} \cdot\left(F-F_{\min }\right) /\left(F_{\max }-F\right)$. Quin 2 measurements of $\left[\mathrm{Ca}^{2+}\right]_{i}$ become nonlinear at concentrations $>1 \mu M$ or saturations of the probe $\geqslant 90 \%$ (\% Quin 2 saturation $\left.=\left(F-F_{\min }\right) /\left(F_{\max }-F_{\min }\right) \times 100 \%\right)$. Reasonably accurate measurement of $\left[\mathrm{Ca}^{2+}\right]_{i}$ can thus be made up to $1 \mu M$. Elevations of $\left[\mathrm{Ca}^{2+}\right]_{i}$ above this level measured with Quin 2 reflect very large increases in $\left[\mathrm{Ca}^{2+}\right]_{i}$ to eventual full equilibrium with the extracellular $\mathrm{Ca}^{2+}$ concentration of $1.5 \mathrm{mM}$.

\section{Fluorescence Microscopy of Adherent Endothelial Cells}

Microfilaments. Endothelial cells were grown in 6-well plates (Nunc) overnight at an approximate density of 1$2 \times 10^{5}$ cells $/ \mathrm{cm}^{2}$. Injury was carried out in MGB after removal of the culture media present. Staining of adherent endothelial cells with fluorescent phallotoxin $[19,26]$ was as follows: a cocktail with final concentrations of $50 \mu \mathrm{g} /$ ml lysophosphatidyl choline, $1.85 \%$ phosphate-buffered formalin, and $165 \mathrm{nM}$ rhodamine phalloidin in MGB was added to the cells washed free of media and then incubated for $10 \mathrm{~min}$ at $37^{\circ} \mathrm{C}$ or $20 \mathrm{~min}$ at room temperature. After another wash step, a glass coverslip was sealed to the monolayer with a small drop of $90 \%$ glycerol.

Microtubules [27]. Adherent endothelial cells prepared as for the morphology experiments described above were fixed with $2 \%$ paraformaldehyde at $37^{\circ} \mathrm{C}$ and then left on ice for $1 \mathrm{hr}$. After washing, the cells were permeabilized with $0.1 \%$ Triton $\mathrm{X}-100$ for $3 \mathrm{~min}$. Following a second wash step with MGB containing $1 \mathrm{mg} / \mathrm{ml}$ bovine serum albumin (Sigma No. 6003), the cells were exposed to $100 \mu \mathrm{l}$ of a 1:30 dilution of the first antibody (rabbit antitubulin; ICN, Immunobiologicals, Lisle, IL) for $20 \mathrm{~min}$ at room temperature. A third wash step was performed and the fluorescent antibody (rhodamine-conjugated goat anti-rabbit IgG; Boehringer-Mannheim, Indianapolis, IN) was added for another 20-min incubation. A coverslip was then sealed to the monolayer with $90 \%$ glycerol.

In some experiments in which double staining of the same cells for both microfilaments and microtubules was done, $165 \mathrm{nM}$ NBD-phallacidin was added to the cells after fixation and permeabilization for $20 \mathrm{~min}$ at room temperature prior to double antibody staining. Stained 
samples were then viewed with a Nikon optiphot fluorescence microscope. Fluorescence micrographs at either 400 or $1000 \times$ magnification were taken using plus $\mathrm{X}$ pan or Tmax film (Kodak).

\section{RESULTS}

\section{Endothelial GSH as a Measure of Oxidant Stress}

To demonstrate that an increasing oxidant load was being experienced by the endothelial cells over the dose range studied, total GSH 60 min after addition of $\mathrm{H}_{2} \mathrm{O}_{2}$ was measured (Fig. 1). A dose-dependent loss of total GSH was seen following exposure to $\mathrm{H}_{2} \mathrm{O}_{2}(P=0.0002$, oneway analysis of variance). Significant reduction of total GSH as compared with control $(P<0.05, t$ test) was seen with concentrations of $\mathrm{H}_{2} \mathrm{O}_{2} \geqslant 5 \mathrm{mM}$.

\section{Endothelial Cell ATP}

ATP levels in bovine pulmonary artery endothelial cells fell rapidly in response to the range $(1-20 \mathrm{mM})$ of $\mathrm{H}_{2} \mathrm{O}_{2}$ doses. Significant dose- and time-dependent reductions of ATP ( $P<0.0001$, two-way analysis of variance) were seen with all concentrations of $\mathrm{H}_{2} \mathrm{O}_{2}$ tested (Fig. 2). There was a tendency toward partial recovery of ATP levels in

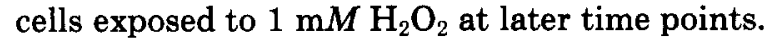

\section{Endothelial Cell $\mathrm{Ca}^{2+}$ Homeostasis following Injury}

Uninjured endothelial cells loaded with Quin 2 had a resting level of $\left[\mathrm{Ca}^{2+}\right]_{\mathrm{i}}$ of approx $200 \mathrm{nM}$. There were significant increases in mean $\left[\mathrm{Ca}^{2+}\right]_{\mathrm{i}}$ following exposure to 5,10 , and $20 \mathrm{mM} \mathrm{H} \mathrm{H}_{2} \mathrm{O}_{2}$ after $60 \mathrm{~min}(P<0.05$, Welch's solution to the Behrens-Fisher problem of unequal variances) [28] (Fig. 3). $\mathrm{H}_{2} \mathrm{O}_{2}$ at $20 \mathrm{mM}$ caused a rapid elevation in mean $\left[\mathrm{Ca}^{2+}\right]_{\mathrm{i}}$ of the entire population of cells to levels $(>1 \mu M)$ after $45-60 \mathrm{~min}$ beyond accurate mea-

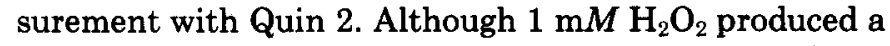
significant reduction in cellular ATP levels, it did not alter $\left[\mathrm{Ca}^{2+}\right]_{\mathrm{i}}$ from the control range (Fig. 3). $\mathrm{H}_{2} \mathrm{O}_{2}$ at 5 and $10 \mathrm{mM}$ produced significant elevations of mean

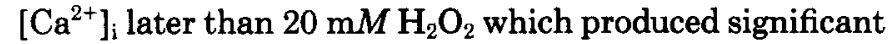
elevation of $\left[\mathrm{Ca}^{2+}\right]_{\mathrm{i}}$ as early as $30 \mathrm{~min}$ after exposure $(P$ $<0.003$; Fig. 3).

When cellular ATP levels were reduced by glucose depletion and $650 \mathrm{nM}$ oligomycin to a range similar to that induced by $\mathrm{H}_{2} \mathrm{O}_{2},\left[\mathrm{Ca}^{2+}\right]_{\mathrm{i}}$ measured by Quin 2 after $1 \mathrm{hr}$ was not significantly altered $\left(0.155 \pm 0.062 \times 10^{-6} \mathrm{M}, N\right.$ $=4$ versus $0.200 \pm 0.055 \times 10^{-6} M, N=14$ for the control, $P>0.05$ ). Addition of $5 \mu M$ ionomycin to the metabolically inhibited endothelial cells loaded with Quin 2 consistently produced rapid, sustained elevation of $\left[\mathrm{Ca}^{2+}\right]_{i}$ to $\geqslant 1 \mu M$ by $1-2 \mathrm{~min}$. Ionomycin alone without prior ATP depletion produced only transient elevations of $\left[\mathrm{Ca}^{2+}\right]_{i}$ lasting for approx $5 \mathrm{~min}$ or less.

\section{Cytoskeletal and Morphologic Changes Associated With Injury}

Exposure to $\mathrm{H}_{2} \mathrm{O}_{2}$ led to dramatic changes in the organization of the endothelial cell cytoskeleton and cellular morphology. After exposure to $\mathrm{H}_{2} \mathrm{O}_{2}$ doses producing a significant decline in ATP levels and significant elevation of mean $\left[\mathrm{Ca}^{2+}\right]_{i}$, there was a rapid disruption of microfilaments into shorter brightly staining aggregates followed by breakup and depolymerization of microtubules. Cell rounding or contraction occurred following disruption of these cytoskeletal structures (Fig. 4). $\mathrm{H}_{2} \mathrm{O}_{2}$ at $1 \mathrm{mM}$ produced some microfilament disruption but no effect on microtubules over the time course of injury (Fig. 4). As a consequence of its lack of effect on $\left[\mathrm{Ca}^{2+}\right]_{i}$ and microtubule organization, $1 \mathrm{mM} \mathrm{H_{2 }} \mathrm{O}_{2}$ caused only subtle changes in endothelial morphology.

When ATP levels were reduced with glucose depletion and exposure to $650 \mathrm{nM}$ oligomycin as shown previously [20], no effect on microtubule organization was seen but microfilament disruption occurred which was very similar if not identical to that seen with $\mathrm{H}_{2} \mathrm{O}_{2}$ injury (Fig. 5). This was consistent with the observation of no change in $\left[\mathrm{Ca}^{2+}\right]_{i}$ under similar conditions in Quin 2-loaded cells.

When $5 \mu M$ ionomycin, a $\mathrm{Ca}^{2+}$ ionophore, was added to the metabolically inhibited cells, rapid disruption and depolymerization of microtubules occurred followed by cell contraction and rounding (Fig. 5). When metabolic inhibition was combined with colchicine $(5 \mu \mathrm{g} / \mathrm{ml})$, which also depolymerizes microtubules, a very similar sequence of events occurred (data not shown). The addition of ionomycin to cells already treated by metabolic inhibition and colchicine did not further enhance the apparent rate of cell rounding/contraction (data not shown).

\section{DISCUSSION}

$\mathrm{H}_{2} \mathrm{O}_{2}$ exposure produced dose-dependent reductions of GSH and ATP and elevation of mean $\left[\mathrm{Ca}^{2+}\right]_{i}$ in bovine

FIG. 5. Fluorescence micrographs of adherent bovine pulmonary artery endothelial cells 60 min after metabolic inhibition with or without exposure to $\mathrm{Ca}^{2+}$ ionophore. (A) Adherent cells stained with NBD-phallacidin 60 min after exposure to $650 \mathrm{n} M$ oligomycin in the absence of glucose ( $1000 \times$ magnification, same field as in B). Note the disruption of microfilaments into brightly staining, shortened aggregates. (B) Adherent. endothelial cells stained with double antibody technique for microtubules 60 min after exposure to oligomycin in the absence of glucose (1000X magnification). Note the normal appearance of microtubules and the minimal change in overall cell morphology. (C) Adherent endothelial cells stained with NBD-phallacidin 60 min after exposure to oligomycin in the absence of glucose and 30 min after addition of ionomycin (1000 $\times$ magnification, same field as in D). Note that the appearance of microfilaments is similar to those in A. (D) Adherent endothelial cells stained with double antibody technique for microtubules $60 \mathrm{~min}$ after exposure to oligomycin in the absence of glucose and 30 min after addition of ionomycin (1000X magnification). Note the loss of linear microtubule staining and the prominent staining around the cell nucleus. Cell contraction and reduction in apparent surface area are also evident. 

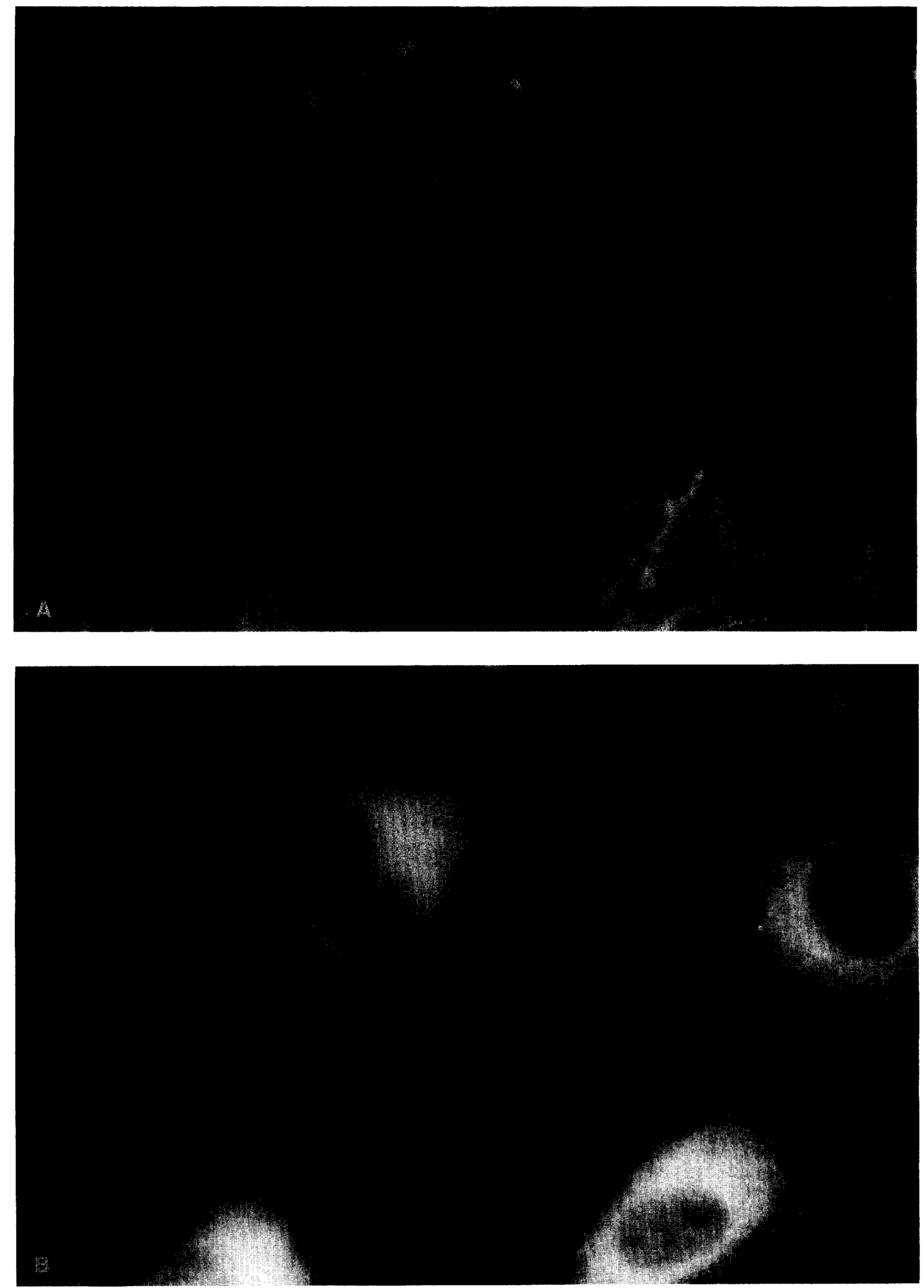

FIG. 5-Continued 

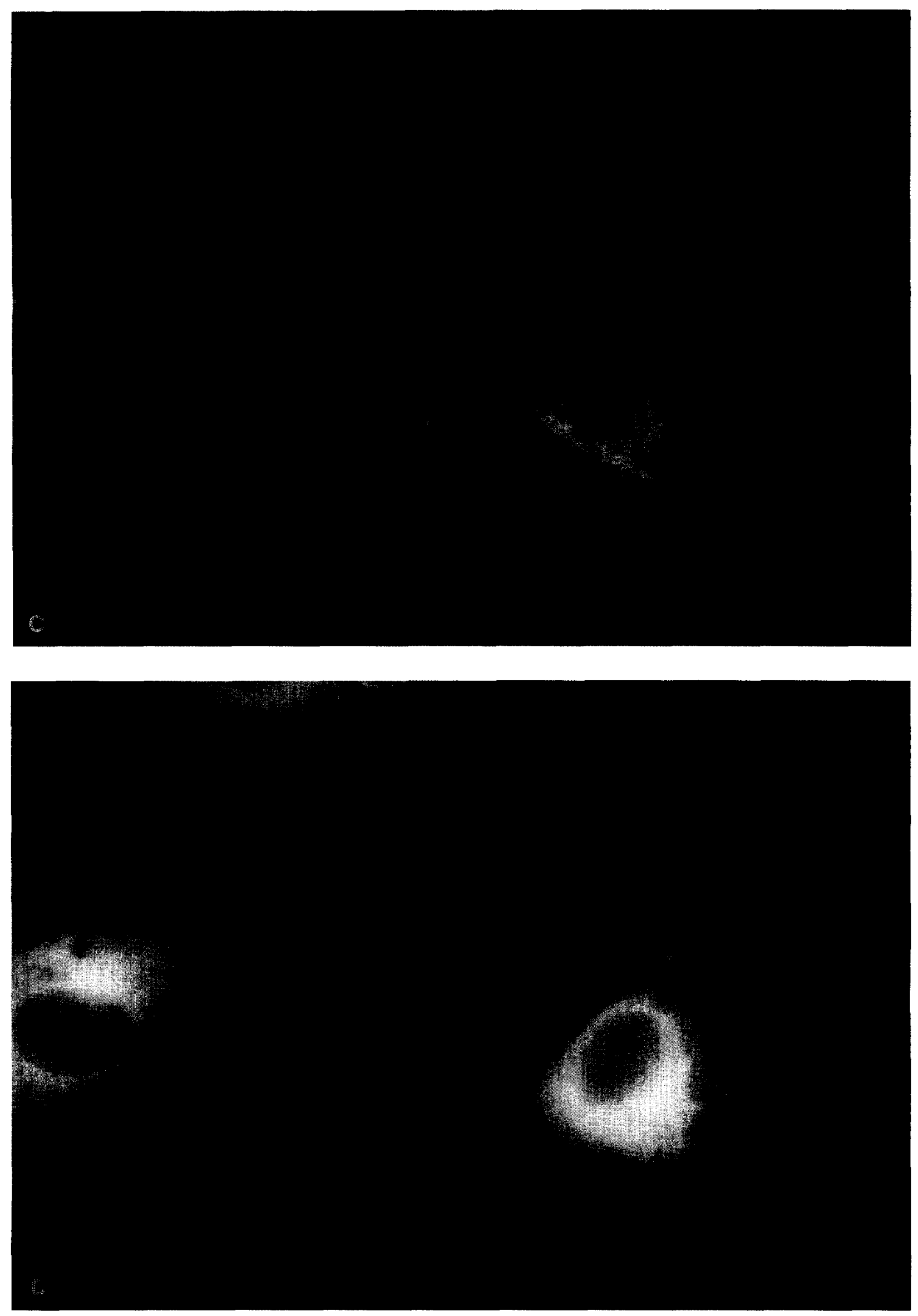

FIG. 5-Continued 
pulmonary artery endothelial cells. It is interesting to note that doses of $\mathrm{H}_{2} \mathrm{O}_{2}$ which produced significant reductions in total GSH also caused significant elevation of $\left[\mathrm{Ca}^{2+}\right]_{i}$.

The close correlation between $\mathrm{H}_{2} \mathrm{O}_{2}$-induced reduction of ATP levels and microfilament disruption (particularly with $1 \mathrm{mM} \mathrm{H} \mathrm{H}_{2} \mathrm{O}_{2}$ where no change in $\left[\mathrm{Ca}^{2+}\right]_{\mathrm{i}}$ occurred) is also strongly supported by earlier work with metabolically inhibited endothelial cells in which a reversible ATP-dependent disruption of microfilaments was demonstrated [20]. The observation that $\left[\mathrm{Ca}^{2+}\right]_{i}$ is remarkably stable for at least an hour in metabolically inhibited cells suggests that something more than reduction of ATP levels is necessary to cause the rapid loss of $\left[\mathrm{Ca}^{2+}\right]_{\mathrm{i}}$ homeostasis seen following $\mathrm{H}_{2} \mathrm{O}_{2}$ exposure at the higher doses. Earlier work [17] with the $\mathrm{P}^{3} 88 \mathrm{D}_{1}$ cell line demonstrated an initial loss of $\mathrm{Ca}^{2+}$ from injured cells in the first few minutes following oxidant exposure, suggesting that $\mathrm{H}_{2} \mathrm{O}_{2}$ may be capable of inducing release of $\mathrm{Ca}^{2+}$ from an oxidant-sensitive intracellular store.

$\left[\mathrm{Ca}^{2+}\right]_{i}$ elevation induced by the higher doses of $\mathrm{H}_{2} \mathrm{O}_{2}$ followed the decline in ATP levels and was correlated closely with the breakup and ultimate depolymerization of microtubules. Although some subtle morphologic changes were seen with microfilament disruption alone, cell contraction and rounding with substantial loss of apparent surface area did not occur unless microtubule depolymerization accompanied the loss of normal microfilament architecture. It is interesting that conditions (e.g., metabolic inhibition) causing microfilament disruption in the P388D $\mathrm{D}_{1}$ cell type which were sufficient to induce cell rounding and contraction [21] did not alter cell shape to the same degree in endothelial cells. Microtubules probably play a more dominant role in maintaining endothelial cell shape than in the $\mathrm{P}_{388 \mathrm{D}_{1} \text { cell line. }}$

To completely disrupt $\left[\mathrm{Ca}^{2+}\right]_{\mathrm{i}}$ homeostasis in the entire endothelial cell population, a relatively large dose (20 $\mathrm{mM}$ ) of $\mathrm{H}_{2} \mathrm{O}_{2}$ was required. Since activated PMN release $\mathrm{H}_{2} \mathrm{O}_{2}$ over very short distances after adhering to endothelial cells, it is possible that the local concentration of $\mathrm{H}_{2} \mathrm{O}_{2}$ at the PMN-endothelial interface may be as high as the millimolar range. It is clear from the effect of 5 and $10 \mathrm{mM} \mathrm{H} \mathrm{H}_{2} \mathrm{O}_{2}$ on mean $\left[\mathrm{Ca}^{2+}\right]_{\mathrm{i}}$ that there is probably a spectrum of $\left[\mathrm{Ca}^{2+}\right]_{\mathrm{i}}$ from the control range to $>1 \mu \mathrm{M}$ in individual cells of the injured population. This implies that individual cells may be responding to $\mathrm{H}_{2} \mathrm{O}_{2}$ with different susceptibilities or that equivalent $\mathrm{H}_{2} \mathrm{O}_{2}$ doses may be delivered inefficiently to each cell in the population when given as a single bolus to the buffer containing the cells.

Sustained elevation of $\left[\mathrm{Ca}^{2+}\right]_{i}$ has been associated with irreversible cell injury [29]. It is interesting to note that a lower dose $(1 \mathrm{mM}) \mathrm{H}_{2} \mathrm{O}_{2}$ injury could produce a significant reduction in endothelial cell ATP levels without affecting $\left[\mathrm{Ca}^{2+}\right]_{i}$, implying that it may represent an ultimately reversible injury. The reduction in ATP levels was still sufficient to induce some microfilament disruption. Since microfilaments may play a crucial role in cell-cell and cell-basement membrane adherence $[11,12]$, it is conceivable that even a reversible oxidant injury may be capable of transiently disrupting the barrier function of the capillary endothelium. This concept may be supported by the observation of Holman et al. [22] that reversible disruption of a model permeability barrier could be induced by oxidant exposure. More massive injury as reflected by the data from the higher $\mathrm{H}_{2} \mathrm{O}_{2}$ doses would presumably be associated with a greater degree of barrier disruption for a longer period of time.

Two important areas of focus for therapy may relate to (1) enhancement of intracellular antioxidant defenses such as augmentation of cellular GSH levels [30] and (2) maintenance or restoration of cellular ATP levels [31]. Increased antioxidant defenses such as higher GSH levels in the target cell might convert a potentially irreversible injury with elevated $\left[\mathrm{Ca}^{2+}\right]_{\mathrm{i}}$ to one with only a transient reduction in ATP levels and a moderate, temporary impairment of function. Maintenance or restoration of ATP levels in injured cells may limit further loss of function by restoring normal microfilament architecture and by maintaining normal $\mathrm{Ca}^{2+}$ pump activity at the cell membrane which would help prevent $\mathrm{Ca}^{2+}$-induced depolymerization of microtubules. Figure 6 outlines in schematic form some of the metabolic consequences of $\mathrm{H}_{2} \mathrm{O}_{2}$ injury and their relationship to alterations in the endothelial cell cytoskeleton and their overall effect on cell shape.

In summary, $\mathrm{H}_{2} \mathrm{O}_{2}$ injury induced a rapid fall in en-
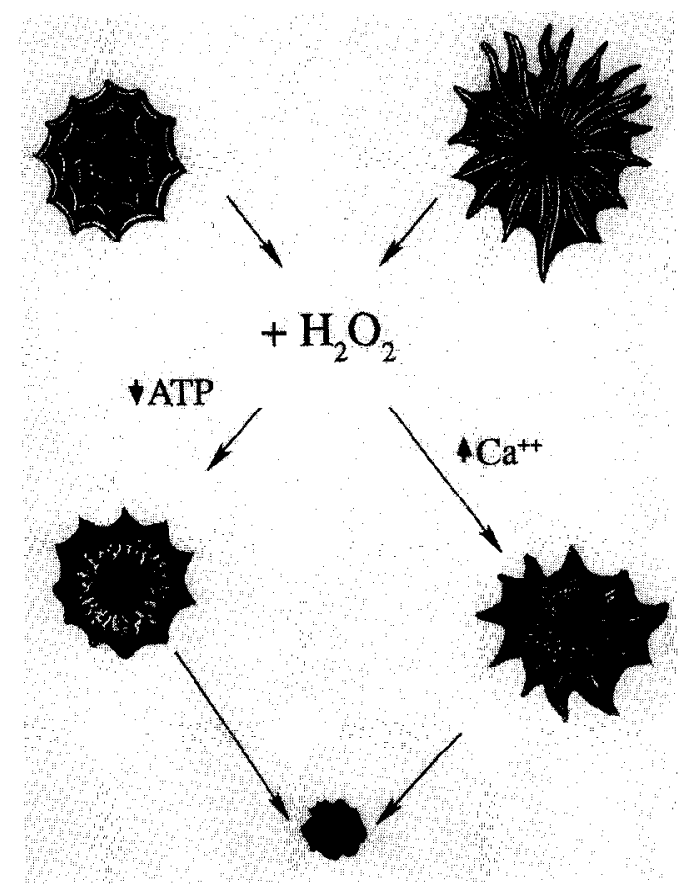

FIG. 6. Diagram of metabolic and associated cytoskeletal effects of $\mathrm{H}_{2} \mathrm{O}_{2}$ injury on endothelial cells. Left-hand side of figure depicts changes in microfilament organization following $\mathrm{H}_{2} \mathrm{O}_{2}$-induced decline in ATP levels. Right-hand side of figure depicts microtubule depolymerization occurring after $\mathrm{H}_{2} \mathrm{O}_{2}$-induced elevation of $\left[\mathrm{Ca}^{2+}\right]_{i}$. 
dothelial cell ATP levels which correlated closely with disruption of microfilaments into shortened aggregates. $\left[\mathrm{Ca}^{2+}\right]_{\mathrm{i}}$ elevation followed the $\mathrm{H}_{2} \mathrm{O}_{2}$-induced decline in ATP levels at higher doses of oxidant and was associated with microtubule depolymerization. The loss of both cytoskeletal structures was then followed by dramatic cell contraction and rounding. These observations may suggest important targets for future therapy.

\section{ACKNOWLEDGMENTS}

The authors thank Dr. David Amato from the Department of Biostatistics, School of Public Health of the University of Michigan, for his expert assistance with the statistical evaluation of the data. They also thank Stacy Wilkinson for her excellent secretarial assistance in preparing the manuscript and the medical media service at the Ann Arbor VAMC for the expert preparation of the illustrations. This work was supported by a Veterans Administration Merit Review Grant to Dr. Hinshaw.

\section{REFERENCES}

1. Majno, G., Gilmore, V., and Leventhal, M. On the mechanism of vascular leakage caused by histamine-type mediators. Circ. Res. 21: 833, 1967.

2. Hurley, J. V. Types of pulmonary microvascular injury. Ann. N.Y. Acad. Sci. 384: 269, 1982.

3. Bisio, J. M., Breen, R. E., Connell, R. S., and Harrison, M. W. Pulmonary capillary endothelial dysfunction in hypoxia and endotoxemia: A biochemical and electron microscope study. $J$. Trauma 23: 730, 1983.

4. Martinez-Palomo, A., Meza, I., Beaty, G., and Cerejido, M. Experimental modulation of occluding junctions in a cultured transporting epithelium. J. Cell Biol. 87: 736, 1980.

5. Meza, I., Ibarra, G., Sabanero, M., Martinez-Palomo, A., and Cereijido, $M$. Occluding junctions and cytoskeletal components in a cultured transporting epithelium. J. Cell Biol, 87: 746, 1980.

6. Shasby, D. M., Shasby, S. S., Sullivan, J. M., and Peach, M. J. Role of endothelial cell cytoskeleton in control of endothelial permeability. Circ. Res. 51: 657, 1982.

7. Shasby, D. M., Lind, S. E., Shasby, S. S., Goldsmith, J. C., and Hunninghake, G. W. Reversible oxidant-induced increases in albumin transfer across cultured endothelium: Alterations in cell shape and calcium homeostasis. Blood 65: 605, 1985.

8. Welsh, M. J., Shasby, D. M., and Husted, R. M. Oxidants increase paracellular permeability in a cultured epithelial cell line. J. Clin. Invest. 76: 1155, 1985.

9. Shasby, D. M., Shasby, S. S., and Peach, M. J. Granulocytes and phorbol myristate acetate increase permeability to albumin of cultured endothelial monolayers and isolated perfused lungs: Role of oxygen radicals and granulocyte adherence. Amer. Rev. Respir. Dis. 127: 72, 1983.

10. Peters, J. H., Ginsberg, M. H., Bohl, B. P., Sklar, L. A., and Cochrane, C. G. Intravascular release of intact cellular fibronectin during oxidant-induced injury of the in vitro perfused rabbit lung. J. Clin. Invest. 78: 1596, 1986.

11. Hynes, R. O., and Destree, A. T. Relationships between fibronectin (LETS protein) and actin. Cell 15: 875, 1978.

12. Chong, A. S. F., Parish, C. R., and Coombe, D. R. Evidence that the cytoskeleton plays a key role in cell adhesion. Immunol. Cell Biol. 65: 85, 1987.
13. Weber, K., and Osborn, M. The cytoskeleton. Natl. Cancer Inst. Monogr. 60: 31, 1982.

14. Deery, W. J., Means, A. R., and Brinkley, B. R. Calmodulin-microtubule association in cultured mammalian cells. J. Cell Biol. 98: 904, 1984.

15. Spragg, R. G., Hinshaw, D. B., Hyslop, P. A., Schraufstatter, I. U., and Cochrane, C. G. Alterations in adenosine triphosphate and energy charge in cultured endothelial and $\mathrm{P}_{388 \mathrm{D}_{1}}$ cells following oxidant injury. J. Clin. Invest. 76: 1471, 1985.

16. Hyslop, P. A., Hinshaw, D. B., Halsey, W. A., Jr., Schraufstatter, I. U., Sauerheber, R. D., Jackson, J. H., Spragg, R. G., and Cochrane, C. G. Mechanisms of oxidant mediated cell injury: The glycolytic and mitochondrial pathways of ADP phosphorylation are major intracellular targets inactivated by $\mathrm{H}_{2} \mathrm{O}_{2}$. J. Biol. Chem. 263: 1665, 1988.

17. Hyslop, P. A., Hinshaw, D. B., Schraufstatter, I. U., Sklar, L. A., Spragg, R. G., and Cochrane, C. G. Intracellular calcium homeo-

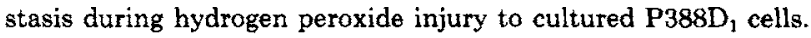
J. Cell. Physiol. 129: 356, 1986.

18. Schraufstatter, I. U., Hinshaw, D. B., Hyslop, P. A., Spragg, R. G., and Cochrane, C. G. Oxidant injury of cells: DNA strand breaks activate poly-ADP-ribose polymerase and lead to depletion of nicotinamide adenine dinucleotide. J. Clin. Invest. 77: 1312, 1986.

19. Hinshaw, D. B., Sklar, L. A., Bohl, B., Schraufstatter, I. U., Hyslop, P. A., Rossi, M. W., Spragg, R. G., and Cochrane, C. G. Cytoskeletal and morphological impact of cellular oxidant injury. Amer. J. Pathol. 123: 454, 1986.

20. Hinshaw, D. B., Armstrong, B. C., Beals, T. F., and Hyslop, P. A. A cellular model of endothelial cell ischemia. J. Surg. Res. 44: 527, 1988.

21. Hinshaw, D. B., Armstrong, B. C., Burger, J. M., Beals, T. F., and Hyslop, P. A. ATP and microfilaments in cellular oxidant injury. Amer. J. Pathol. 132: 479, 1988.

22. Holman, R., Soderland, C., and Maier, R. Oxidant induced endothelial leak correlates with decreased cellular energy levels. Circ. Shock 24: 250, 1988. [Abstract]

23. Brehe, J. E., and Burch, H. B. Enzymatic assay for glutathione. Anal. Biochem. 74: 189, 1976.

24. Stanley, P. E., and Williams, S. G. Use of the liquid scintillation spectrometer for determining adenosine triphosphate by the luciferase enzyme. Anal. Biochem. 29: 281, 1969.

25. Tsien, R. Y., Pozzan, T., and Rink, T. J. Calcium homeostasis in intact lymphocytes: Cytoplasmic free calcium monitored with a new, intracellularly trapped fluorescent indicator. J. Cell Biol. 94: $325,1982$.

26. Howard, T. H., and Meyer, W. H. Chemotactic peptide modulation of actin assembly and locomotion in neutrophils. J. Cell Biol. 98: $1265,1984$.

27. Wang, K., Feramisco, J. R., and Ash, J. F. Fluorescent localization of contractile proteins in tissue culture cells. In W. Lands and W. Smith (Eds.), Methods in Enzymology. New York, Academic Press, 1982. Vol. 85, pp 514-562.

28. Bickel, P. J., and Doksum, K. A. Mathematical Statistics: Basic Ideas and Selected Topics. Oakland, CA: Holden-Day, 1977. Pp 218-219.

29. Farber, J. L. Minireview: The role of calcium in cell death. Life Sci. 29: 1289, 1981.

30. Anderson, M. E., Powrie, F., Puri, R. N., and Meister, A. Glutathione monoethyl ester: Preparation, uptake by tissues, and conversion to glutathione. Arch. Biochem. Biophys. 239(2): 538, 1985.

31. Weinberg, J. M., and Humes, H. D. Increases of cell ATP produced by exogenous adenine nucleotides in isolated rabbit kidney tubules. Amer. J. Physiol. 250: F720, 1986. 